\title{
RESPON MASYARAKAT TERHADAP PERINGATAN BERGAMBAR PADA KEMASAN ROKOK DI KABUPATEN SLEMAN DAERAH ISTIMEWA YOGYAKARTA
}

\author{
Rama Nur Kurniawan. K \\ Bagian Promosi Kesehatan, Fakultas Masyarakat, Universitas Pancasakti \\ Makassar
}

\section{ABSTRAK}

Upaya menekan permasalahan rokok, pemerintah tak henti-hentinya turut menanggulangi masalah yang ditimbulkan oleh perilaku merokok. Peraturan Pemerintah No. 28 Tahun 2013 yang menekankan pada pencantuman bahaya merokok dalam bentuk gambar pada semua kemasan rokok, mengacu pada sebuah teori komunikasi yang disebut sebagai teori The Extended Parallel Process Model (EPPM) dengan menggunakan pendekatan kesan menakutkan (fear appeals). Tujuan dari penelitian ini adalah untuk mengeksplorasi respon masyarakat terhadap peringatan pesan bergambar pada kemasan rokok. Penelitian ini menggunakan metode kualitatif dengan disain grounded theory untuk mengeksplorasi respon masyarakat terhadap peringatan pesan bergambar pada kemasan rokok. Pengumpulan data dilakukan dengan triangulasi metode, wawancara mendalam dan diskusi kelompok terarah (DKT). Hasil penelitian memaparkan bahwa; 1) perasaan jijik, takut/ngeri saat melihat gambar, diperkuat dengan keyakinan terhadap kebenaran gambar akan menimbulkan respon menolak, sedangkan perasaan biasa saja yang diperkuat dengan ketidakyakinan akan menimbulkan reaksi menerima gambar, 2) Ada masa penyesuaian masyarakat terhadap peringatan pesan bergambar pada kemasan rokok. 3) gambar memperkuat niat non perokok untuk semakin tidak merokok, dan tidak mempengaruhi perokok untuk berhenti merokok. 4) gambar dianggap efektif sebagai media edukasi untuk non perokok. Penelitian menyimpulkan bahwa: 1) tindakan masyarakat terhadap peringatan pesan bergambar pada kemasan rokok dipengaruhi oleh faktor perasaan dan keyakinan akan kebenaran gambar. 2) durasi masa penyesuiaan terhadap gambar berlangsung selama $\pm 2-3$ bulan, 3) peringatan pesan bergambar belum mampu menyentuh emosi masyarakat secara kultural dan membuat perokok untuk berhenti merokok.

Kata kunci: Pesan peringatan, kemasan rokok, fear appeals, gambar, perasaan 


\section{PENDAHULUAN}

Perilaku merokok merupakan suatu kebiasaan yang sangat membahayakan bagi kesehatan, yang sampai saat ini masih merupakan masalah di kalangan generasi muda dan masyarakat di Indonesia. Data Centers for Disease Control and Prevention (CDC) menunjukkan bahwa merokok dapat meningkatkan risiko terkena penyakit tidak menular salah satunya adalah kanker. Jika hal ini tidak ditangani, diperkirakan pada tahun 2030 sebanyak 1 miliar jiwa akan melayang akibat konsumsi tembakau/rokok yang terjadi di negara-negara berkembang (CDC, 2014) Menurut data GATS (2014) menyebutkan dari aspek pengetahuan, sikap dan persepsi, sebanyak $86.0 \%$ dari orang dewasa percaya bahwa merokok menyebabkan beberapa penyakit kronis. Hasil lain menunjukkan bahwa perilaku merokok justru mengalami peningkatan, dicermati dari data Susenas 2001, yang mencatat sekitar $31,8 \%$ orang Indonesia merokok (Kemenkes RI, 2011). Kebijakan terbaru dalam upaya menekan jumlah perokok di negara ini adalah dengan diterbitkannya Peraturan Pemerintah No 109/2012 dan Permenkes No 28/2013. Kebijakan ini menekankan pencantuman peringatan pesan bergambar (pictorial health warning) pada kemasan produk tembakau, yang diberlakukan sejak 24 Juni 2014 dan telah dianggap efektif di beberapa negara (Febrida, 2014).

Penelitian ini bertujuan untuk mengeksplorasi respon masyarakat perkotaan Kabupaten Sleman Daerah Istimewa Yogyakarta terhadap peringatan pesan bergambar pada kemasan rokok.

\section{METODE}

Penelitian ini menggunakan metode kualitatif dengan disain grounded theory. Penelitian dilakukan di Kecamatan Depok, sebagai representasi wilayah perkotaan yang berada di Kabupaten Sleman Daerah Istimewa Yogyakarta. Metode pengumpulan data dilakukan dengan menggunakan metode observasi partisipasi, wawancara mendalam dan diskusi kelompok terarah (DKT) (Utarini, 2014).

Observasi partisipasi dilakukan dengan cara mencoba mengikuti beberapa aktivitas informan guna mengamati perilaku merokok. Wawancara mendalam dilakukan kepada 14 orang, yang terdiri atas 7 orang perokok dan 7 orang non perokok. DKT dilakukan kepada 
informan perokok dan informan non perokok.

Hasil pengumpulan data observasi, wawancara mendalam dan DKT dibuat dalam bentuk transkrip, untuk memudahkan dalam proses analisis data. Hasil transkrip dimasukkan dalam aplikasi open code untuk dilakukan proses koding, selanjutnya dibuat menjadi kategori. Proses terakhir dalam analisis data adalah melakukan axial coding dengan cara mencari hubungan dari beberapa hasil kategori, baik yang bersifat temporal maupun kausal hingga kemudian terbentuk sebuah pola (Bugin, 2008).

\section{HASIL DAN PEMBAHASAN}

Perasaan saat melihat pesan bergambar pada kemasan rokok

Informan beranggapan

bahwa gambar pada kemasan rokok adalah hal yang biasa saja serta tidak menimbulkan perasaan apapun saat melihatnya. Hasil serupa di tunjukkan oleh penelitian Hakkak (2014), yang menyatakan bahwa gambar kemasan rokok tidak memunculkan perasaan takut terhadap dampak buruk dari merokok seperti yang telah tertuang dalam kemasannya.

Perasaan lain yang dirasakan informan saat melihat gambar peringatan pada kemasan rokok adalah perasaan kasihan, jijik dan takut. Menurut Widati (2013), mengatakan pemberian fotofoto pada kemasan rokok diharapkan mampu membuat konsumen berfikir berulangkali sebelum memutuskan untuk merokok. Hal yang paling penting diperhatikan dalam membuat pesan yang menakutkan baik dalam bentuk kalimat ataupun gambar adalah daya tarik rasa takut tersebut, harus berada pada tingkat moderat dan bisa diterima oleh segmentasi sasaran dari pesan, sehingga mereka mampu mengikuti atau menjalankan hal-hal yang disarankan dalam sebuah pesan (Sanjaya, 2012).

Keyakinan terhadap kebenaran peringatan pesan bergambar

Informan

meyakini

kebenaran gambar pada kemasan rokok sebagai sebuah fakta medis yang diyakini telah melalui proses penelitian secara ilmiah. Menurut Bandura (2006), penilaian seseorang dalam meyakini sebuah objek dipengaruhi oleh keadaan fisiologis dari individu itu sendiri. Gejolak emosi yang hadir, dan keadaan fisiologis yang dialami oleh individu akan ditunjang oleh stimulan objek yang ditemukan. Perilaku akan dipengaruhi oleh norma subjektif, yakni berupa 
kepercayaan individu terhadap suatu rujukan tertentu dari sebuah perilaku, baik yang harus dilakukan atau tidak boleh dilakukan (Ajzen, 1991). Informan yang tidak yakin terhadap kebenaran gambar peringatan disebabkan karena informan belum mempunyai pengalaman secara langsung melihat kerabat atau orang terdekatnya mengalami kejadian seperti yang dijelaskan dalam gambar peringatan kemasan rokok. Senada dengan yang dikemukakan oleh Romer dkk (2013), bahwa keyakinan diri yang rendah dari para perokok tentang fakta gambar, akan berpengaruh pada lemahnya keinginan berhenti merokok. Pengalaman kesuksesan diri sendiri, merupakan faktor yang mempuyai pengaruh sangat besar terhadap keyakinan diri individu (Taylor, 2010).

Tindakan

masyarakat terhadap peringatan pesan bergambar pada kemasan rokok

Tindakan masyarakat terhadap gambar peringatan kemasan rokok dipengaruhi oleh faktor perasaan dan keyakinan. Informan dengan perasaan biasa saja ataupun sekedar heran/kaget saat melihat gambar yang tertera pada kemasan rokok, jika diperkuat oleh ketidakyakinan terhadap kebenaran dari gambar tersebut, akan memunculkan sikap masa bodoh atau tidak melakukan tindakan-tindakan tertentu. Informan dengan perasaan kasihan, takut/ngeri dan merasa jijik saat melihat gambar, yang diperkuat dengan keyakinan akan kebenaran gambar, maka akan melakukan tindakan-tindakan untuk menghindari gambar peringatan tersebut. Tindakan informan dalam menghindari gambar, seperti; memilih-milih gambar kemasan saat membeli rokok, menyiapkan kemasan rokok portable, menyobek bagian gambar, menutup bagian gambar dengan alat perekat, hingga menyobek gambar. Kemasan rokok yang dipilih oleh masyarakat adalah kemasan dengan gambar orang merokok sambil menggendong anak dan gambar orang merokok dengan latar tengkorak (Choiri, 2015).

\section{Masa penyesuaian terhadap peringatan pesan bergambar} Tindakan masyarakat dalam menghindari gambar kemasan rokok yang dianggap memunculkan rasa kasihan, takut dan jijik, tidak berlangsung lama. Ada proses penyesuaian yang dilakukan oleh masyarakat terhadap gambar peringatan pada kemasan rokok, sehingga menurunkan 
nilai efektifitas dari paparan gambar tersebut. Penurunan efektifitas ini merubah perasaan yang dulunya jijik, takut dan menimbulkan rasa kasihan, menjadi perasaan yang biasa saja, sehingga perubahan perasaan tersebut menyebabkan pula perubahan tindakan, dari tindakan menghindari, menjadi tindakan dengan kategori menerima. Berdasarkan hasil penelitian ditemukan, bahwa masa penyesuaian yang dialami masyarakat hanya berkisar selama 2-3 bulan, kurang dari 3 bulan, bahkan sebagian menuturkan hanya berlangsung selama 1 minggu. Peringatan pesan bergambar pada kemasan rokok di Kanada dan Amerika Serikat, memperoleh hasil, bahwa telah terjadi penurunan efektivitas paparan gambar kemasan rokok di kedua negara tersebut dari waktu ke waktu (Hitchman, 2014).

\section{Perilaku merokok masyarakat} Kelompok masyarakat non perokok, memperkuat niat/keinginan untuk semakin tidak merokok. Peringatan kesehatan bergambar yang tertera pada kemasan rokok, merupakan media untuk melakukan pemberian informasi dan edukasi yang murah dan efektif kepada masyarakat (Sugandi, 2009).
Untuk kelompok masyarakat perokok dengan kategori perokok ringan, dapat membantu mengurangi jumlah konsumsi rokok. Peringatan pesan bergambar pada kemasan rokok lebih efektif bagi kalangan perokok pemula (Blanton, 2014).

Untuk

kelompok

masyarakat dengan kategori perokok berat, tidak ada perubahan perilaku untuk berhenti merokok ataupun mengurangi jumlah konsumsi rokok. Remaja yang telah ketergantungan rokok lebih cenderung bersikap masa bodoh dengan ancaman penyakit yang telah tertera pada kemasan rokok (Pepper dkk, 2013).

\section{KESIMPULAN}

Kesimpulan

dari penelitian ini adalah tindakan masyarakat terhadap peringatan pesan bergambar pada kemasan rokok dipengaruhi oleh faktor perasaan yang dirasakan saat melihat gambar dan keyakinan terhadap kebenaran gambar. Perasaan jijik, takut dan mengerikan yang diperkuat dengan keyakinan terhadap kebenaran gambar, akan menimbulkan respon menolak, sedangkan perasaan biasa saja yang diperkuat dengan ketidakyakinan akan kebenaran gambar, tidak akan 
menimbulkan respon/tindakan tertentu (menerima). Ada masa penyesuaian terhadap efektivitas peringatan pesan bergambar yang berlangsung selama 2-3 bulan. Peringatan pesan bergambar pada kemasan rokok, dianggap efektif bagi masyarakat non perokok dan perokok pemula, sebagai media edukatif dalam menambah tentang bahaya rokok. Peringatan pesan bergambar belum mampu menyentuh emosi masyarakat secara kultural dan membuat perokok untuk berhenti merokok.

\section{REKOMENDASI}

Berdasarkan hasil penelitian, maka dianggap perlu memberikan saran kepada pembuat kebijakan yaitu: 1) Semua kemasan rokok sebaiknya menampilkan gambar tentang keparahan penyakit akibat rokok, untuk menghindari perilaku memilihmilih gambar kemasan rokok, 2) Perlunya memperbesar ukuran dari disain gambar pada kemasan rokok, 3) Perlunya melakukan penambahan atau mengganti gambar pada kemasan rokok secara periodik.

\section{DAFTAR PUSTAKA}

Ajzen, I. (1991). The Theory of Planned Behavior. Organizational behavior and human decision processes 50, 179-211. http : // www . nottingham ac .uk / ntzcl1/ literature / tpb / azjen2.pdf [Diakses 26 November 2015].

Bandura, A. (2006). SelfEfficacy: Beliefs of Adolescents. Information Age

Publishing.Availablefrom

https://books.google.co.id lbooks.

Blanton. (2014) Effect of Graphic Cigarette Warnings on Smoking Intenton in Young Adults. PLOS ONE. Vol. 9. Issue. 5.

Brata, W (2012). Tembakau atau Mati. Kesaksian, Kegelisahan, dan Harapan Seorang Petani Tembakau. Jakarta: Indonesia Berdikari.

Bugin, B. (2008) Analisis Data Penelitian Kualitatif. Jakarta: PT. Rajagrafindo Persada. 
CDC. (2014) What You Need to Know About Smoking: Advice from Surgeon General 's Reports on Smoking and Health, Surgeon General's Report on Smoking \& Health, Atlanta, available at: http : / / www. cdc. gov/ tobacco/data_statistics /sgr /50th anniversary/index.htm\#re port.

Choiri (2015). Hubungan Antara Pengetahuan dan Sikap Terhadap

Gambar

Penyakit Akibat Merokok Yang Terdapat Dalam Kemasan Rokok Dengan Perilaku Merokok Masyarakat di Kelurahan Purwosari. Naskah Publikasi. Prodi Ilmu Kesehatan Masyarakat. Fakultas Kesehatan Masyarakat Universitas Muhammadiyah

Surakarta. Available from : http:// eprints. ums. ac.id /35448/

(Tidak dipublikasi).

Depkes, RI. (2008) Laporan Hasil Riskesdas Provinsi Daerah Istimewa Yogyakarta Tahun 2007.

Febrida. (2014) 24 Juni, Semua Bungkus Rokok Harus Bergambar Seram! [internet]. from:http://health.liputan6 .com [Di Akses, 8 Oktober 2014).

GATS. (2011). Global Adult Tobacco Survey. Indonesia.

Hakkak. (2014) Pictorial Health Warning Labels on Cigarette Packages: An Investigation on Opinions of Male Smokers. Department of Biostatistics and Information Technology, School of Nursing and Midwifery, Mashhad University.

Hidayangsih. (2009) FaktorFaktor yang Berhubungan dengan Perilaku Berisiko Remaja di Kota Makassar Tahun 2009. Buletin Penelitian Kesehatan. Vol 39, No 2. (Akses, 6 Oktober 2014).

Hitchman, S.C (2014). Changes in effectiveness of cigarette health warnings over time in canada and the United States, 20022011. Nicotine and \begin{tabular}{lll} 
Tobacco & Research \\
\hline Volume 16, Issue 5.
\end{tabular} Article number ntt196, Pages 536-543. Available from : http://www-scopus com.ezproxy.ugm.ac.id. 
[Akses, 19 November 2015].

Kemenkes RI. (2013) Riskesdas 2013. Jakarta : Badan Penelitian dan Pengembangan Kesehatan.

Pepper, J.K., Cameron, L.D., Reiter, P.L., Mcree, A. and Brewer, N.T. (2013), "Non-Smoking Male Adolescents 'Reactions to Cigarette Warnings", PloS one, Vol. 8 No. 8, doi:10.1371/journal.pone. 0065533.

Romer D, Peters E, Strasser AA, Langleben D (2013) Desire versus Efficacy in Smokers' Paradoxical Reactions to Pictorial Health Warnings for Cigarettes. PLOS ONE. Vol. 8. Issue. 1

Sanjaya, S.D (2012) Pengaruh Fear Appeals, Endosr dan Jingle Dalam Iklan Suzuki Nex Di Televisi Versi Band $\mathrm{SM}^{\star} \mathrm{SH}$ Terhadap Respon Konsumen. Graduasi.Vol.28.Availabl efrom:http://jurnal.stiesur akarta.ac.id/index.php/gr aduasi/article/view/31. (Diakses, 2 Januari 2015).
Sugandi. A. (2009). Situasi Sosial Politik menghadapi Pemilu 2009: Tantangan dan Peluang untuk Advokasi Pengendalian Tembakau". Presentasi pada Workshop Jaringan Pengendalian Dampak Tembakau, Novotel Bogor, 11-13 Janauari 2009.

Taylor, M. (2010) Applications of self-efficacy theory to the understanding and treatment of career indecision. Journal of Vocational Behaviour. Vol. 22 Issue 1. Pages 63-81.

Utarini, A . (2014) Modul Mata Kuliah : Metode Penelitian Kualitatif. Yogyakarta: Fakultas Kedokteran UGM.

Widati. (2013) Daya Ungkit IImu Komunikasi Pemasaran Agar Masyarakat Berperilaku Sehat Tanpa Rokok. Jurnal Promkes. Ikatan Ahli Kesehatan Masyarakat Indonesia. Vol.1 No.1 [Akses, 6 Oktober 2014] 